\title{
SISTEM ADMINISTRASI AKADEMIK JURUSAN D3 AKUNTANSI BERBASIS TEKNOLOGI INFORMASI
}

\author{
Lucy Sri Musmini ${ }^{1)}$, Ni Ketut Kertiasih ${ }^{2)}$ \\ 'Jurusan Akuntansi, Undiksha (Penulis 1) \\ email: musmini@yahoo.co.id, \\ 2Jurusan Manajemen Informatika, Undiksha (Penulis 2) \\ email: tut_kerti@yahoo.com
}

\begin{abstract}
Abstrak
Perkembangan teknologi informasi dapat mempermudah dan mempercepat kegiatan yang dilakukan oleh sistem administrasi akademik. Tujuan penelitian ini adalah mengembangkan sistem administrasi akademik berbasis teknologi informasi Jurusan D3 Akuntansi Undiksha.

Metode yang digunakan pada penelitian ini adalah metode pengembangan, dalam hal ini studi kasus pengembangan sebuah sistem administrasi akademik berbasis teknologi pada Jurusan D3 Akuntansi.

Hasil penelitian ini adalah analisis sistem, yang terdiri dari analisis kelemahan dan kebutuhan sistem, dan desain sistem, yang terdiri dari desain konteks, flowchart, dan desain sistem riil. Sistem yang dikembangkan terkait dengan kegiatan akademik mahasiswa, dosen, dan jurusan. Akses input sistem dapat dilakukan oleh mahasiswa, dosen, dan administrasi, sedangkan akses output sistem dapat dilakukan oleh dosen dan administrasi. Administrasi jurusan dalam penelitian ini adalah sekretaris jurusan. Informasi yang diperoleh dari sistem adalah kegiatan akademik mahasiswa, dosen, dan jurusan pada Jurusan D3 Akuntansi. Implikasi penelitian ini adalah sistem adminstrasi akademik jurusan yang semakin efektif dan efisien.
\end{abstract}

Kata kunci: Sistem, Administrasi Akademik, dan Teknologi Informasi

\begin{abstract}
The purpose of this research is to develop academic administration system based on technology information for D3 Accounting Department, Undiksha.

The method used in this research is the development method with case study to develop academic administration system based on technology information at the Department of Accounting D3.

The results are the analysis of the system, which consists of the analysis of the weaknesses and needs of the system, and the design of the system, which consists of the design context, flowchart, and the design of the real system. The system developed and obtained information related to academic activities of students, lecturer, and department. Access to system input can be done by students, lecturer, and administration, while access to the system output can be done by the lecturer and administration. Administration majoring in this research is the department secretary. Implication of this research is the major system of academic administration more effective and efficient.
\end{abstract}

Keywords : Systems, Academic Administration, and Information Technology

\section{PENDAHULUAN}

Perkembangan teknologi informasi saat ini sungguh sangat pesat, tanpa kita sadari saat ini teknologi informasi telah menjadi suatu kebutuhan bagi para

\begin{tabular}{llr} 
pemakainya. & \multicolumn{2}{c}{ Berbagai bidang } \\
memperoleh dukungan dari teknologi \\
informasi, tidak terkecuali bidang \\
pendidikan. Pada pengelolaan dan \\
manajemen informasi di bidang
\end{tabular}


pendidikan, yang memanfaatkan teknologi informasi telah banyak dilakukan oleh para peneliti. Semua penelitian tersebut bertujuan untuk mempermudah pemakai informasi memperoleh akses informasi yang merupakan output dari proses yang dikerjakan oleh teknologi informasi. Salah satu bidang pendidikan yang didukung oleh teknologi informasi adalah sistem administrasi akademik jurusan di perguruan tinggi.

Sistem administrasi akademik jurusan adalah suatu kebutuhan yang sangat mendasar dalam mengelola jurusan, karena semua aktivitas di jurusan yang bersangkutan tentunya dapat direkam pada sistem tersebut. Adanya sistem administrasi akademik jurusan dapat membatu pemakai memberikan informasi tentang kemahasiswaan, dosen, karya ilmiah, statistik mahasiswa, nilai, kegiatan, informasi akademik, dan lainlain.

Penguatan tata kelola di tingkat jurusan sangat diperlukan untuk mendukung penilaian kinerja jurusan atau program studi oleh lembaga eksternal lembaga, salah satunya oleh Badan Akreditasi Nasional Perguruan Tinggi (BAN-PT). Pemanfaatan sistem administrasi akademik berbasis teknologi informasi dapat meningkatkan tata kelola jurusan, terutama dalam hal pelayanan informasi tentang data akademik jurusan serta pengambilan keputusan untuk menunjang pengembangan lembaga tersebut.

Saat ini pemanfaatan teknologi informasi sebagai pendukung sistem administrasi akademik jurusan sangat penting untuk dikembangkan oleh masingmasing jurusan, karena jurusan adalah mesin utama dari pelaksanaan akademik bagi sebuah lembaga perguruan tinggi. Beberapa penelitian menyatakan bahwa sistem administrasi akademik lembaga pendidikan memang masih belum dapat dikatakan baik, diantaranya pada penelitian Yazdi, M (2009) tentang perlunya pengembangan desain data warehouse akademik untuk mendukung sistem administrasi data akademik di Universitas Tadulako, sedangkan penelitian Afriyuni, D (2013) mengemukakan tentang rancangan pengembangan sistem informasi administrasi akademik terintegrasi dengan menggunakan jaringan di Tunas Patria.

Pada sisi lain, penelitian Indrayani (2011) menguji sejauh mana sumbangan efektifitas manajemen SIA (sistem informasi akademik), budaya TIK (teknologi informasi dan komunikasi), kesediaan fasilitas TIK dan kualitas SDM SIA terhadap kinerja perguruan tinggi dengan responden manajemen lembaga, dosen, dan mahasiswa. Hasil penelitian menunjukkan bahwa efektifitas manajemen SIA (sistem informasi akademik), budaya TIK (teknologi informasi dan komunikasi), kesediaan fasilitas TIK dan kualitas SDM SIA berpengaruh secara signifikan terhadap kinerja perguruan tinggi.

Berdasarkan penelitian-penelitian tersebut menunjukkan bahwa pengembangan sistem administrasi akademik sangatlah penting. Dengan adanya sistem administrasi akademik yang handal diharapkan pelayanan administrasi akademik dapat dioptimalkan dengan menghasilkan informasi yang akurat, relevan, dan tepat waktu.

Jurusan D3 Akuntansi adalah salah satu jurusan yang bernaung di bawah Fakultas Ekonomi dan Bisnis Universitas Pendidikan Ganesha. Saat ini sistem administrasi akademik Jurusan D3 Akuntansi masih dilakukan secara manual dan belum terintegrasi. Adapun administrasi akademik yang dilakukan sangat kompleks, diantaranya administrasi mahasiswa, dosen, kegiatan-kegiatan akademik jurusan lainnya. Adanya perkembangan teknologi yang sangat pesat saat ini, sudah selayaknya Jurusan D3 Akuntansi membuat perubahan pada sistem administasi akademik yang diterapkan selama ini, menjadi sistem yang berbasis teknologi informasi. Berdasarkan uraian di atas, penelitian ini akan memfokuskan pada pengembangan sistem administrasi akademik Jurusan D3 Akuntansi berbasis teknologi informasi.

Berdasarkan latar belakang masalah dan fokus penelitian maka rumusan masalah penelitian ini adalah sistem administrasi akademik berbasis teknologi 
informasi bagaimanakah yang sesuai dikembangkan pada Jurusan D3 Akuntansi?

Apabila diuraikan lebih rinci lagi, maka pertanyaan penelitian yang ingin dijawab pada penelitian ini adalah sebagai berikut:

a. Bagaimanakah penerapan sistem administrasi akademik pada Jurusan D3 Akuntansi?

b. Bagaimanakah pengembangan sistem administrasi akademik berbasis $\mathrm{TI}$ yang sesuai pada Jurusan D3 Akuntansi.

Sesuai dengan rumusan masalah yang dikemukakan pada penelitian ini maka tujuan penelitian ini adalah untuk mengembangkan sistem administrasi akademik Jurusan D3 Akuntansi berbasis teknologi informasi. Adapun secara khusus penelitian ini bertujuan untuk:

a. Mengetahui penerapan sistem administrasi akademik pada Jurusan D3 Akuntansi

b. Mengembangkan sistem administrasi akademik berbasis TI pada Jurusan D3 Akuntansi.

\section{METODE}

Pendekatan penelitian ini memakai perspektif ruang lingkup (luas dan kedalaman) topik yaitu berupa penelitian studi kasus. Studi kasus lebih menekankan kepada analisis konteks secara penuh berdasarkan peristiwa atau kondisi yang sangat sedikit dan melihat hubungannya satu dengan lainnya. Studi kasus sangat tepat untuk penyelesaian masalah, evaluasi, dan strategi karena menekankan pada hal-hal yang bersifat rinci, yang diperoleh dari berbagai sumber informasi, bukti-bukti dapat diverifikasi dan data yang hilang dapat dihindari. Metode yang digunakan adalah metode pengembangan, dalam hal ini pengembangan sebuah sistem administrasi akademik berbasis teknologi, khususnya pada Jurusan D3 Akuntansi.

Pada penelitian ini yang menjadi subjek penelitian adalah pengelola, staf dosen dan mahasiswa Jurusan D3 Akuntansi Undiksha, sedangkan objek penelitian ini adalah sistem administrasi akademik Jurusan D3 Akuntansi. Data yang diperlukan pada pengembangan sistem administrasi akademik ini dikumpulkan melalui beberapa metode yaitu:

1. Observasi, merupakan suatu proses yang kompleks, suatu proses yang tersusun dari pelbagai proses biologis dan psikologis, pada penelitian ini yang diobservasi adalah kegiatan sistem administrasi akademik Jurusan D3 Akuntansi yang diterapkan selama ini.

2. Wawancara yaitu memahami sistem administrasi akademik Jurusan D3 Akuntansi yang ada serta mengidentifikasi permasalahan yang ada dengan melakukan tanya jawab dan diskusi dengan pihak terkait seperti kajur, sekjur, kalab, staf dosen dan mahasiswa.

Penelitian ini merupakan penelitian pengembangan yaitu metode penelitian yang digunakan untuk menghasilkan produk tertentu dan menguji keefektifan produk tersebut. Dalam hal ini produknya berupa perangkat lunak sistem administrasi akademik berbasis TI Jurusan Akuntansi Program Dipoma III. Adapun tahap penelitian yang dilakukan ada empat tahap yaitu:

1) Tahap studi pendahuluan, dilakukan dengan pendekatan deskriptif kualitatif.

Penelitian ini akan diawali dengan penelitian/pengamatan pendahuluan pada objek penelitian. Kegiatan yang dilakukan adalah mengadakan observasi dan wawancara pada pengelola, staf dosen, dan mahasiswa tentang sistem administrasi akademik yang diterapkan saat ini, kesulitan-kesulitan yang dialami terkait dengan sistem administrasi akademik yang diterapkan, serta kebutuhan yang diperlukan oleh pemakai informasi. Tahap berikutnya, adalah melakukan telaah pustaka tentang sistem administrasi akademik berbasis teknologi informasi pada sebuah lembaga pendidikan. Berdasarkan pengamatan pendahuluan dan telah pustaka tersebut dapat diketahui dan diidentifikasi masalah yang dihadapi oleh pengelola jurusan mengenai sistem administrasi akademik yang diterapkan saat ini, sehingga dapat 
dibuatkan suatu usulan penelitian tentang topik tersebut.

Selanjutnya, berdasarkan usulan yang dibuat, dilakukan kegiatan pengumpulan data yang berkaitan dengan pengembangan sistem administrasi akademik berbasis teknologi pada jurusan D3 Akuntansi. Sesuai dengan metodologi pengembangan sistem, kegiatan yang dilakukan pada penelitian ini adalah tahapan analisis sistem dan desain sistem. Analisis sistem adalah kegiatan yang mendeskripsikan sistem yang sedang berjalan, masalah, dan rekomendasi umum untuk memperbaiki, meningkatkan atau mengganti sistem yang sedang berjalan (Al Fatta, 2007). Tujuan utama tahap analisis adalah memahami dan mendokumentasikan kebutuhan bisnis dan proses dari sistem baru. Pada tahap analisis terdapat beberapa kegiatan yang perlu dilakukan yaitu:

a. Pengumpulan informasi

Langkah awal pada tahapan analisis adalah mengumpulkan informasi tentang bagaimana proses-proses bisnis yang ada pada sistem lama, kemudian pada bagaimana saja dari proses bisnis yang mengalami masalah atau kelemahan untuk diidentifikasi dan diperbaiki dengan sistem baru.

b. Mendefinisikan sistem requirement

Berdasarkan informasi kelemahan system yang ditemukan, selanjutnya mendefinisikan apa saja yang sebenarnya dibutuhkan oleh sistem lama untuk mengatasi masalahnya.

c. Memprioritaskan kebutuhan

Pada tahap ini akan ditentukan prioritas kebutuhan yang paling mendesak, karena mungkin kebutuhan perbaikan system yang perlu dilakukan sangat banyak.

d. Menyusun dan mengevaluasi alternatif Setelah menyusun dan memprioritaskan kebutuhan, selanjutnya harus juga disiapkan alternatif jika seandainya prioritas kebutuhan tidak sesuai dengan kebutuhan pemakai informasi.

e. Mengulas kebutuhan dengan pihak pemakai informasi
Mengulas kebutuhan yang sudah ada dengan pihak pengelola jurusan, staff dosen dan mahasiswa.

2) Tahap pengembangan desain sistem administrasi akademik berbasis TI Jurusan Akuntansi Program Dipoma III dengan pendekatan deskriptif.

Tahapan desain adalah proses mengubah kebutuhan yang masih berupa konsep menjadi spesifikasi sistem yang riil. Dalam hal ini akan dikembangkan sistem berbasis teknologi informasi yang sesuai dengan kebutuhan pemakai. Pada tahun pertama, luaran penelitian yang dihasilkan berdasarkan proses di atas adalah berupa suatu prototype model awal sistem administrasi akademik berbasis teknologi informasi.

Pengembangan perangkat lunak yang dilakukan pada penelitian ini menggunakan aplikasi berbasis web yang terdiri atas dari dua bagian besar yaitu tampilan dan database. Tampilan dibuat dengan menggunakan HTML (Hyper Text Markup Language) dan PHP. HTML digunakan untuk membuat tampilan web sehingga tampilan menjadi indah. PHP digunakan untuk melakukan transfer data dari server ke client dan penulisan PHP dalam web terintegrasi dengan HTML. Database menggunakan SQL dengan MySQL sebagai aplikasi databasenya.

3) Tahap penerapan uji coba terbatas dengan metode eksperimen (single one shot case study). Setelah perbaikan desain, dilakukan lagi uji coba yang lebih luas dengan metode eksperimen (one group pretestpostest).

4) Tahap validasi menggunakan metode eksperimen (one group pretestpostest)

Tahapan 3 dan 4 akan dilaksanakan pada tahun kedua. Saat sistem administrasi akademik berbasis teknologi informasi yang dikembangkan telah memperoleh hasil berupa prototype model awal, maka hasil tersebut akan diimplementasikan dan diuji coba pada peristiwa yang sesungguhnya yang terjadi 
pada Jurusan D3 Akuntansi. Jika ada ditemukan kelemahan sistem yang dihasilkan, maka dilakukan revisi terhadap sistem tersebut sampai dinilai cukup memadai sesuai dengan kebutuhan pemakai. Luaran pada tahun kedua adalah teknologi sistem informasi akademik serta publikasi berupa artikel ilmiah berdasarkan penelitian ini.

\section{HASIL DAN PEMBAHASAN}

\section{A. Hasil Pengembangan Sistem \\ Administrasi Akademik}

Sistem administrasi akademik jurusan saat ini, maka perlu diidentifikasi kebutuhan sistem informasi administrasi akademik yang lebih baik. Adapun yang dikelola pada sistem informasi administrasi akademik yang terdiri dari data jurusan, dosen, dan mahasiswa saat ini diuraikan berikut ini.

Data mahasiswa terdiri dari:

a. Data mahasiswa (profil mahasiswa, KRS, KHS)

b. Data akademik mahasiswa (transkrip nilai akhir, laporan PKL, laporan TA, artikel TA).

c. Data lulusan (data yudisium).

d. Data produk akademik mahasiswa selain PKL dan TA.

Data dosen terdiri dari:

a. Data dosen (profil dosen, kepangkatan (sk), tugas mengajar (sk), tugas penelitian (surat tugas), tugas pengabdian (surat tugas), tugas pendukung (surat tugas/piagam), termasuk jabatan lain staff dosen di lembaga.

b. Data produk akademik dosen (buku ajar, model pembelajaran, dll,)

c. Data penelitian dosen (laporan).

d. Data pengabdian dosen (laporan)

e. Data publikasi dosen (artikel publikasi jurnal atau makalah penyaji seminar).

Data jurusan terdiri dari:

a. Data pengelola jurusan (data setiap masa tugas (sk), home based dosen).

b. Data evaluasi diri jurusan (akreditasi BAN PT, AMAI)

c. Data perkuliahan (jadwal mata kuliah setiap semester, kelas, dosen pengampu). d. Data kurikulum, SAP, silabus, deskripsi mata kuliah.

e. Data kegiatan jurusan lain (seminar jurusan, kuliah kerja lapangan, dII).

Berdasarkan kebutuhan sistem adminstrasi akademik yang telah dianalisis, berikut desain sistem.

1) Diagram konteks.

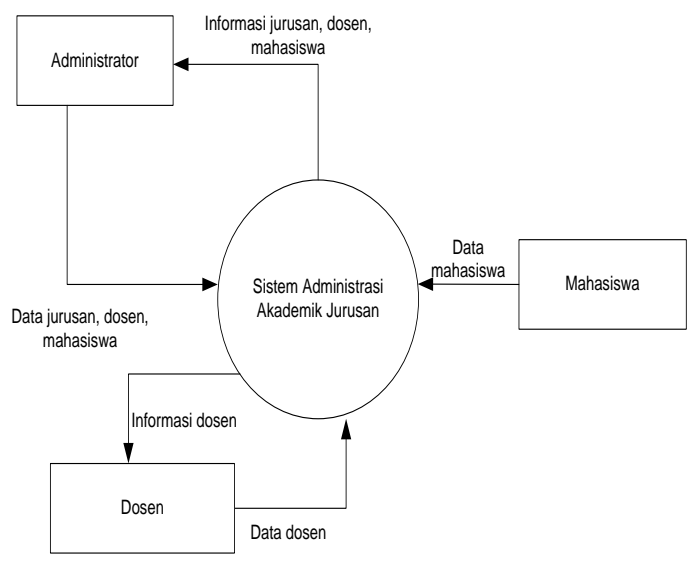

Gambar 1. Diagram Konteks

\section{Tampilan Hasil Pengembangan}

Beberapa tampilan hasil pengembangan SIAA Jurusan Akuntansi yang telah dikembangkan sebagai berikut.

a. Tampilan Halaman login

Halaman login berfungsi untuk melakukan akses kepada sistem informasi administrasi akademik Jurusan Akuntasi. Terdapat tiga pengguna/user utama dalam sistem ini yaitu mahasiswa, dosen dan administrator.

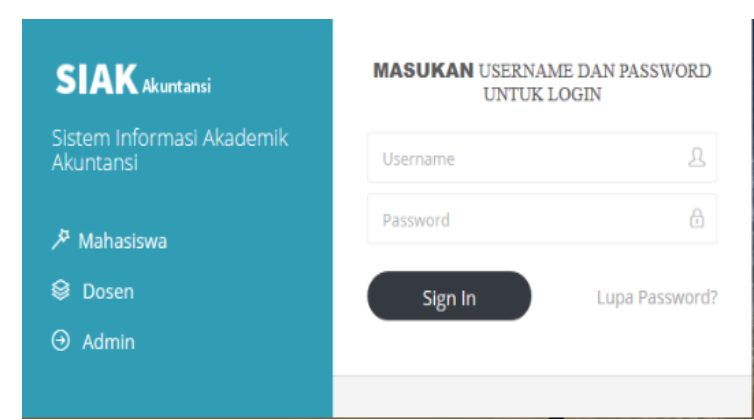

Gambar 2. Tampilan Halaman Login

b. Tampilan Halaman Utama

Halaman ini merupakan halaman utama dari sistem informasi akademik jurusan Akuntasi yang terlihat pertama kali ketika user membuka sistem. 


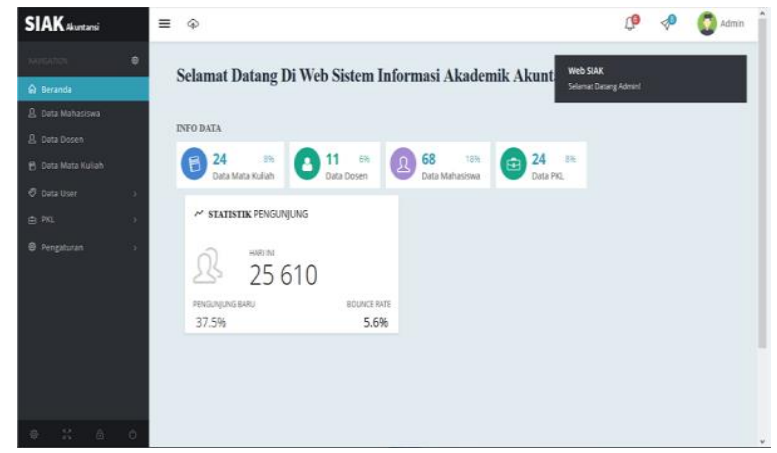

Gambar 3. Tampilan Halaman Utama

c. Tampilan Halaman Data Mata Kuliah

Pada halaman ini digunakan untuk mengelola mata kuliah seperti proses untuk menambah data, menghapus data maupun memperbaiki data mata kuliah yang sebelumnya pernah diinputkan.
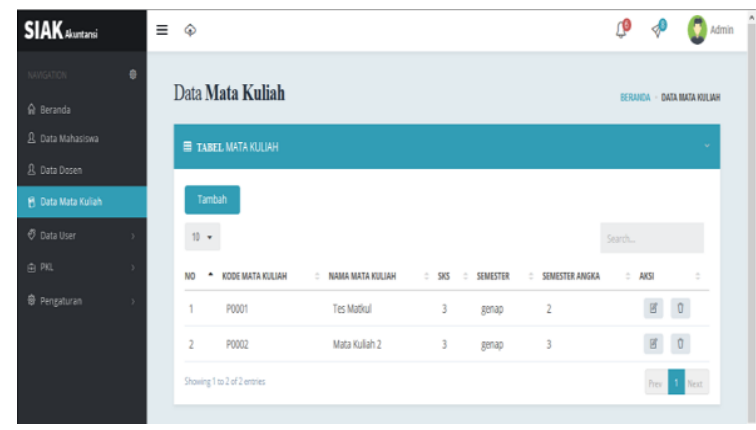

Gambar 4. Tampilan Halaman Data Mata Kuliah

\section{d. Tampilan Halaman untuk Mengelola Data Dosen}

Pada halaman ini digunakan untuk mengelola data dosen seperti proses untuk menambah data, menghapus data maupun memperbaiki data dosen yang sebelumnya pernah diinputkan.

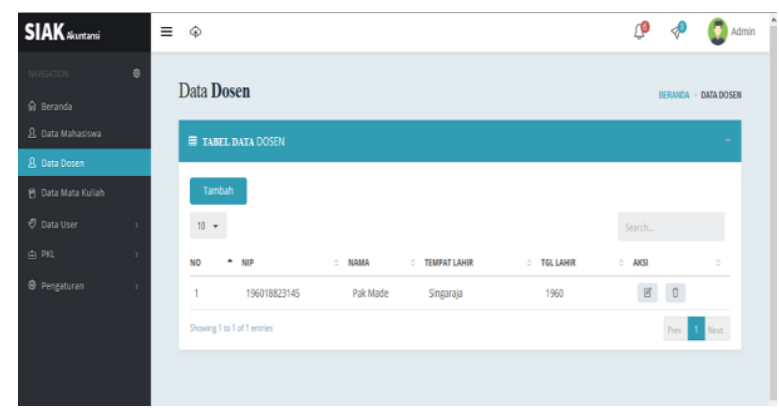

Gambar 5. Tampilan Halaman untuk Mengelola Data Dosen

\section{B. Pembahasan}

Kegiatan pada perguruan tinggi lebih banyak terjadi di jurusan yang menjadi bagian dari perguruan tinggi. Kegiatan yang paling utama adalah kegiatan akademik, disamping kegiatan lain yang menjadi pendukung kegiatan akademik tersebut. Kegiatan akademik memerlukan adminstrasi untuk mendokumentasikan atau merekam semua kegiatan yang terjadi di jurusan. Informasi yang diperoleh dari datanadminstrasi jurusan dapat digunakan sebagai dasar perencanaan dan evaluasi kegiatan jurusan. Informasi ini sangat bermanfaat terutama bagi pengelola jurusan, selain itu juga bagi staf dosen dan mahasiswa.

Pada Jurusan D3 Akuntansi, adminstrasi akademik jurusan dilakukan oleh sekretaris jurusan dibantu oleh staf dosen lainnya. Semua aktivitas di jurusan didokumentasikan dari awal semester sampai akhir semester, dari awal penerimaan mahasiswa sampai mahasiswa tersebut tamat. Kegiatan awal semester dimulai dengan mengajukan penawaran mata kuliah, rapat penentuan pemegang mata kuliah, pengisian KRS bagi mahasiswa, pembuatan jadwal perkuliahan lengkap dengan ruangan dan dosen pengampu), proses perkuliahan yang awali dengan pemberian silabus dan sap, peroses perkulihan disertai tugas, UTS, dan UAS, selanujnya proses penilaian dan remidi, pengumuman nilai mahasiswa, dan pengumuman KHS mahasiswa. Aktivitas mahasiswa sejak menjadi mahasiswa baru sampai tamat juga mempunyai catatan akademik yang diadministrasikan di jurusan seperti profil mahasiswa, transkrip nilai, laporan PKL, laporan TA, dan artikel TA.

Kegiatan dosen sebagai elemen jurusan memiliki kegiatan tri darma perguruan tinggi yang harus diarsipkan. Kegiatan pengajaran, penelitian, pengabdian pada masyarakat, publikasi ilmiah, kepangkatan, profil dosen, dan kegiatan penunjang didokumentasikan juga oleh jurusan. Administrasi akademik dosen sangat bermanfaat untuk melakukan penilaian terhadap kinerja dosen dalam setiap periode. 
Kegiatan dalam pengelolaan jurusan perlu diadminstrasikan untuk mengetahui kegiatan apa yang telah dilakukan jurusan mencakup bidang perkuliahan, kegiatan akademik jurusan, evaluasi diri jurusan, seminar jurusan, kurikulum, dan kegiatan lembaga yang diikuti oleh jurusan.

Informasi sistem diukur dengan laporan yang dihasilkan dari data yang dimilki. Informasi akademik sangat diperlukan oleh pengelola jurusan untuk mengambil keputusan. Sistem yang baik dapat menghasilkan informasi yang berkualitas. Informasi yang dimiliki jurusan masih berupa data, sehingga masih perlu dibuatkan ringkasan yang merupakan laporan agar informasi dapat diperoleh.

Penilaian sistem yang paling umum dilihat dari sudut pandang ekonomi. Sistem dapat mengurangi biaya adminstrasi, dapat menjadi lebih hemat dan keuntungan dari peningkatan nilai informasi dan keputusan yang dihasilkan. Penghematan dengan adanya sistem informasi dapat diperoleh dari komputer. Jurusan tidak lagi menyiapkan lemari dan rak untuk menyimpan folder-folder berisi arsip seperti saat ini, yang dapat berdampak pada pengurangan kebutuhan ruang penyimpanan arsip.

Efisiensi mengacu pada waktu yang digunakan untuk menyediakan informasi. Dokumen yang merupakan data jurusan dengan adanya sistem ini dapat mempermudah untuk mencari data yang diperlukan untuk membuat informasi. Dengan adanya sistem ini juga pelayanan menjadi semakin baik, kemudahan akses yang dibutuhkan untuk menyediakan informasi yang diminta.

\section{SIMPULAN DAN SARAN}

Berdasarkan hasil penelitian tentang sistem administrasi akademin jurusan D3 Akuntansi yang diperoleh, maka dapat diambil kesimpulan berikut ini:

1. Penerapan sistem administrasi akademik jurusan D3 Akuntansi masih bersifat manual dan menggunakan arsip berupa dokumen dari kertas. Saat diperlukan informasi tentang kegiatan di dalam jurusan, baik itu untuk mahasiswa, dosen, dan jurusan, memerlukan cukup banyak waktu untuk pencarian dan pemrosesan informasi tersebut.

2. Pengembangan sistem administrasi akademik jurusan D3 Akuntansi dilakukan dengan sistem yang berbasis teknologi informasi melalui tahap: analisis kelemahan sistem, analisis kebutuhan sistem, desain konteks sistem, desain flowchart sistem dan desain sistem riil.

Saran yang dapat disampaikan berkaitan dengan sistem administrasi akademik jurusan D3 Akuntansi adalah sebagi berikut:

1. Pengembangan sistem administrasi akademik jurusan D3 Akuntansi baru pertama kali dilakukan dengan cakupan kegiatan mahasiswa, dosen dan jurusan. Pada tahap selanjutnya dapat dikembangkan sistem yang mencakup kegiatan alumni, organisasi kemahasiswaan, jurnal jurusan dan informasi-informasi fakultas dan universitas yang terkait dengan jurusan.

2. Bagi staff jurusan perlu diluangkan waktu untuk memahami sistem administrasi akademik jurusan D3 Akuntansi sehingga manfaat sistem dapat diperoleh secara maksimal.

\section{DAFTAR PUSTAKA}

Afriyuni, D. 2013. Rancangan Pengembangan Sistem Informasi Administrasi Akademik Terintegrasi Dengan Menggunakan Jaringan (Studi Kasus Di Tunas Patria). Tesis Universitas Gunadarma.

Al Fatta, H.2007. Analisis dan Perancangan Sistem Informasi untuk Keunggulan Bersaing Perusahaan dan Organisasi Modern.Andi Offset. Yogyakarta.

Bodnar, H.G. dan Hopwood. S.W. 2006. Sistem Informasi Akuntansi. Edisi 9. Penerbit Andi. Yogyakarta.

Cooper, D. dan Emory, C. 1999. Metode Penelitian Bisnis. Edisi Kelima. Jilid 1. Penerbit Erlangga. Jakarta. 
Fathansyah. 1999. Basis Data. Bandung: Informatika.

George H. Bodnar/Wliam S. Hopwood / Amir Abadi Jusuf/ Rudi M. Tambunan, 2000. Sistem Informasi Akuntansi penerbit Salemba Empat Pearson Education Asia Pte.Ltd.

Indrayani, E. 2011. Pengelolaan Sistem Informasi Akademik Perguruan Tinggi Berbasis Teknologi Informasi Dan Komunikasi. Jurnal Penelitian dan Pendidikan. Vol. 12, No. 1. April.

Kadir, A. 1999. Konsep dan tuntunan praktis basis data. Yogyakarta: Penerbit ANDI.

Kristanto, H. 1994. Konsep dan Perancangan Database. Yogyakarta: Andi Offset.

Kristanto, Y. 2007. Desain web e-learning sebagai alternatif pembelajaran di Jurusan Kurikulum dan Teknologi Pendidikan Universitas Negeri Semarang. Skripsi. di Jurusan Kurikulum Dan Teknologi Pendidikan Universitas Negeri Semarang. Tersedia pada http://digilib. unnes.ac.id/gsdl/collect/skripsi/ archives/HASH0199/8d00fc93.dir/do c.pdf.

Mulyadi. 2001. Sistem Akuntansi. Edisi ke 3. Penerbit Salemba Empat. Jakarta.

Nawawis, W. 2010. Pengaruh kualitas pelayanan administrasi akademik online terhadap kepuasan mahasiswa. Skripsi Universitas Sultan Ageng Tirtayasa.

Romney, B.M. dan Steinbart. J.P. 2005. Sistem Informasi Akuntansi. Jilid 1. Edisi 9. Selemba Empat. Jakarta.

Sugianto, D., Renaldy, H. \& Sjargi, M. F. 2003. Langkah demi langkah membangun website dengan PHP. Jakarta: Datakom Lintas Buana.

Sugiyono. 2008. Metode Penelitian Pendidikan. Bandung: Alfabeta
Sutabri, T. 2004. Sistem Informasi Akuntansi. Yogyakarta: Penerbit Andi.

Widjajanto, N. 2001. Sistem Informasi Akuntansi. Penerbit Erlangga. Jakarta

Yazdi, M. 2009. Desain Datawarehouse Akademik Untuk Mendukung Sistem Administrasi Data Akademik Di Universitas Tadaluko. Jurnal IImiah Matematika Terapan. Vol 6, No.2. November. 